\title{
Acute liver failure caused by 'fat burners' and dietary supplements: A case report and literature review
}

\author{
Y Radha Krishna MBBS 1 , V Mittal MD ${ }^{1}$, P Grewal MD ${ }^{1}$, MI Fiel MD², T Schiano MD
}

\begin{abstract}
Y Radha Krishna, V Mittal, P Grewal, MI Fiel, T Schiano. Acute liver failure caused by 'fat burners' and dietary supplements: A case report and literature review. Can J Gastroenterol 2011;25(3):157-160.
\end{abstract}

Globally, people are struggling with obesity. Many effective, nonconventional methods of weight reduction, such as herbal and natural dietary supplements, are increasingly being sought. Fat burners are believed to raise metabolism, burn more calories and hasten fat loss. Despite patient perceptions that herbal remedies are free of adverse effects, some supplements are associated with severe hepatotoxicity. The present report describes a young healthy woman who presented with fulminant hepatic failure requiring emergent liver transplantation caused by a dietary supplement and fat burner containing usnic acid, green tea and guggul tree extracts. Thorough investigation, including histopathological examination, revealed no other cause of hepatotoxicity. The present case adds to the increasing number of reports of hepatotoxicity associated with dietary supplements containing usnic acid, and highlights that herbal extracts from green tea or guggul tree may not be free of adverse effects. Until these products are more closely regulated and their advertising better scrutinized, physicians and patients should become more familiar with herbal products that are commonly used as weight loss supplements and recognize those that are potentially harmful.

Key Words: Dietary supplements; Hepatotoxicity; Liver failure; Liver transplantation

$\mathrm{n}$ recent years, there has been an alarming increase in obesity worldwide. Growing numbers of obese individuals are struggling to find the best way to lose weight. This has created an enormous industry for weight loss and related health products. Because they are not subject to regulatory testing by the United States Food and Drug Administration (FDA), herbal remedies continue to be a popular choice due to their perceived safety and easy availability. Among the more popular remedies are the 'fat burners'. These supplements are advertised to work by increasing thermogenesis and the basal metabolic rate, thus, mimicking exercise. Despite the common perception that these natural supplements are free of side effects, some are associated with severe toxicities including hepatotoxicity.

Several slimming aids and herbal medications associated with severe hepatotoxicity have been reported in the literature. The list is long, and examples of a few are the following: Chaso, Onshind, Sennomotounou (Japan); Green tea extracts (eg, Exolise [ArkoPharma-France]); Hydroxycut (Iovate, Canada); The Right Approach (PharmanexUSA); LipoKinetix (Syntrax, USA); Ma Hung; Pure usnic acid; Kombucha mushroom; Teucrium chamaedrys (germander); Teucrium capitum; and Teucrium polium (golden germander) (1-4).

The present report describes a case of acute liver failure in a young healthy female taking herbal supplements containing usnic acid, green tea and guggul tree extracts.

\section{L'insuffisance hépatique aiguë causée par les «brûleurs de graisse » et les compléments alimentaires : un rapport de cas et une analyse bibliographique}

Sur la scène mondiale, les gens luttent contre l'obésité. Ils se tournent de plus en plus vers de nombreuses méthodes efficaces et non conventionnelles de réduction du poids, telles que les suppléments alimentaires naturels et à base de plantes médicinales. Ils pensent que les brûleurs de graisse activent le métabolisme, brûlent plus de calories et accélèrent la perte de matières grasses. Malgré les perceptions des patients selon lesquelles les produits à base de plantes médicinales ne provoquent pas d'effets secondaires, certains suppléments s'associent à une grave hépatotoxicité. Le présent rapport décrit le cas d'une jeune femme en santé qui a consulté en raison d'une insuffisance hépatique foudroyante exigeant une greffe du foie d'urgence, consécutive à la consommation d'un supplément alimentaire contenant de l'acide usnique, du thé vert et des extraits de guggul. Un examen approfondi, y compris un examen histopathologique, n'a révélé aucune autre cause d'hépatotoxicité. Ce cas s'ajoute au nombre croissant de rapports d'hépatotoxicité associée à des suppléments alimentaires contenant de l'acide usnique et attire l'attention sur le fait que des plantes médicinales extraites du thé vert ou du guggul peuvent entraîner des effets secondaires. Tant que ces produits ne feront pas l'objet d'une réglementation plus stricte et que leur publicité ne sera pas mieux évaluée, les médecins et les patients devraient se familiariser avec les plantes médicinales couramment utilisées comme suppléments de perte de poids et repérer ceux qui ont un potentiel nuisible.

\section{A previously healthy 28-year-old female bodybuilder with no risk factors} for liver disease presented to her local emergency centre with fatigue, malaise, inability to exercise and new-onset jaundice. Her symptoms worsened over a span of one week before hospitalization. Initially, she was confused, and over two days became obtunded and eventually required intubation for airway protection before her transfer to The Mount Sinai Medical Center (New York, USA) for liver transplant evaluation.

The patient was a professional bodybuilder taking a multi-ingredient, nonstimulant health supplement and fat burner (Somalyz and Lipolyz, Species Nutrition, USA). Somalyz contains usnic acid (4 mg), propionylL-carnitine $(167 \mathrm{mg})$, phosphatidylcholine/phosphatidylethanolamine (50 mg), gamma-aminobutyric acid (667 mg) and vitamin E (27 IU) per capsule. Lipolyz contains usnic acid (12 $\mathrm{mg}$ ), propionyl-L-carnitine $(500 \mathrm{mg})$, green tea extract $(300 \mathrm{mg})$, guggulsterone $\mathrm{Z}$ and guggulsterone $\mathrm{E}(10 \mathrm{mg})$, cyclic adenosine monophosphate $(2 \mathrm{mg})$ and vitamin E (20 IU) per capsule (Table 1). She was taking one to two capsules of Somalyz at bedtime and one capsule of Lipolyz with meals three times a day as recommended for one month before illness. Her other medications included over-the-counter calcium and fibre supplements, and caffeine tablets.

On evaluation at The Mount Sinai Medical Center, there were no stigmata of chronic liver disease. Blood work revealed a total

${ }^{1}$ Division of Liver Diseases; ${ }^{2}$ Department of Pathology, Recanati/Miller Transplantation Institute, The Mount Sinai Medical Center, New York, New York, USA

Correspondence: Dr Priya Grewal, Department of Hepatology, The Mount Sinai Medical Center, One Gustave Levy Place, New York,

New York 10029, USA. Telephone 646-709-4486, fax 212-241-4131, e-mail priya.grewal@mountsinai.org

Received for publication May 3, 2010. Accepted July 30, 2010 
TABLE 1

Composition of dietary supplements taken by the patient

\begin{tabular}{|c|c|c|c|}
\hline \multicolumn{2}{|l|}{ Lipolyz* } & \multicolumn{2}{|l|}{ Somalyz* } \\
\hline${\text { Active } \text { ingredient }^{\dagger}}^{\dagger}$ & Dose & $\overline{\text { Active ingredient }}^{\dagger}$ & Dose \\
\hline Vitamin E & $20 \mathrm{IU}$ & Vitamin E & $27 \mathrm{IU}$ \\
\hline Propionyl-L-carnitine & $500 \mathrm{mg}$ & GABA & $667 \mathrm{mg}$ \\
\hline Green tea extract & $300 \mathrm{mg}$ & Propionyl-L-carnitine & $167 \mathrm{mg}$ \\
\hline Usnic acid & $12 \mathrm{mg}$ & Phosphatidylcholine/ & $50 \mathrm{mg}$ \\
\hline $\begin{array}{l}\text { Guggulsterone } \mathrm{Z} \text { and } \\
\text { guggulsterone } \mathrm{E}\end{array}$ & $10 \mathrm{mg}$ & phosphatidylethanolamine & \\
\hline C-Amp & $2 \mathrm{mg}$ & Usnic acid & $4 \mathrm{mg}$ \\
\hline Capsule composition & & Melatonin & $1 \mathrm{mg}$ \\
\hline Gelatin & & Capsule composition & \\
\hline Other ingredients & & Gelatin & \\
\hline Magnesium stearate & & Other ingredients & \\
\hline Rice flour & & Magnesium stearate & \\
\hline & & Rice flour & \\
\hline
\end{tabular}

*Species Nutrition, USA; ${ }^{\dagger}$ Per capsule. C-Amp Cyclic adenosine monophosphate; GABA Gamma-aminobutyric acid

serum bilirubin level of $82.08 \mathrm{mmol} / \mathrm{L}$ (normal range $1.71 \mathrm{mmol} / \mathrm{L}$ to $20.5 \mathrm{mmol} / \mathrm{L})$, a direct bilirubin level of $47.88 \mathrm{mmol} / \mathrm{L}(1.71 \mathrm{mmol} / \mathrm{L}$ to $13.6 \mathrm{mmol} / \mathrm{L})$, a serum alanine aminotransferase level of $1220 \mathrm{U} / \mathrm{L}$ (1 U/L to $53 \mathrm{U} / \mathrm{L})$, a serum aspartate aminotransferase level of $577 \mathrm{U} / \mathrm{L}$ ( $1 \mathrm{U} / \mathrm{L}$ to $50 \mathrm{U} / \mathrm{L})$, an alkaline phosphatase level of $111 \mathrm{U} / \mathrm{L}$ (30 U/L to $110 \mathrm{U} / \mathrm{L})$, a gamma-glutamyl transferase level of $125 \mathrm{U} / \mathrm{L}$ (8 U/L to $35 \mathrm{U} / \mathrm{L})$, an international normalized ratio of 2.6 and a serum creatinine level of $53.04 \mu \mathrm{mol} / \mathrm{L}(44.2 \mu \mathrm{mol} / \mathrm{L}$ to $106.2 \mu \mathrm{mol} / \mathrm{L})$. Her hematological markers, electrolyte levels, metabolic profile, amylase levels and lipase values were unremarkable.

Etiological workup included the following: negative viral serology (hepatitis A virus immunoglobulin $\mathrm{M}$, hepatitis B virus surface antigen and core antibody, hepatitis $\mathrm{C}$ virus antibody [polymerase chain reaction assay], cytomegalovirus DNA and Epstein-Barr virus immunoglobulin $\mathrm{M}$ ); negative syphilis rapid plasma regain; negative autoimmune markers (antinuclear antibody, antiliver kidney muscle antibody, antimitochondrial antibody and antismooth muscle antibody); and normal serum gamma globulins. Extensive toxicology screening was negative, with no features of acetaminophen toxicity (acidosis, high lactate or renal failure). She had normal levels of ferritin, ceruloplasmin and alpha-1 antitrypsin. A pregnancy test was negative. A computed tomography scan of her abdomen revealed a normal size liver with a patent portal vein, hepatic artery, hepatic vein and normal biliary anatomy. Her spleen was normal and no ascites was noted.

The patient's encephalopathy worsened and she remained unresponsive. A computed tomography scan of her head was normal. An intracranial pressure monitor was placed, which measured an intracranial pressure of $19 \mathrm{mmHg}$ and a cerebral perfusion pressure of $77 \mathrm{mmHg}$ to $82 \mathrm{mmHg}$. She underwent successful cadaveric orthotopic liver transplantation on hospital day 2. By postoperative day 4 , she was awake and alert. She experienced no significant postoperative complications and was discharged home for outpatient follow-up.

Histopathological examination of the liver explant showed massive hepatic necrosis and parenchymal collapse, with a few islands of ductular regeneration (Figures 1 and 2).

\section{DISCUSSION}

Usnic acid is a component of nutritional supplements that are promoted for weight loss and have been associated with liver-related adverse events including mild hepatic toxicity, chemical hepatitis and liver failure requiring liver transplantation. Usnic acid is derived from a lichen species of the genus Usnea. It has been investigated for diverse uses as an antimicrobial, an anti-inflammatory, an antioxidant, an

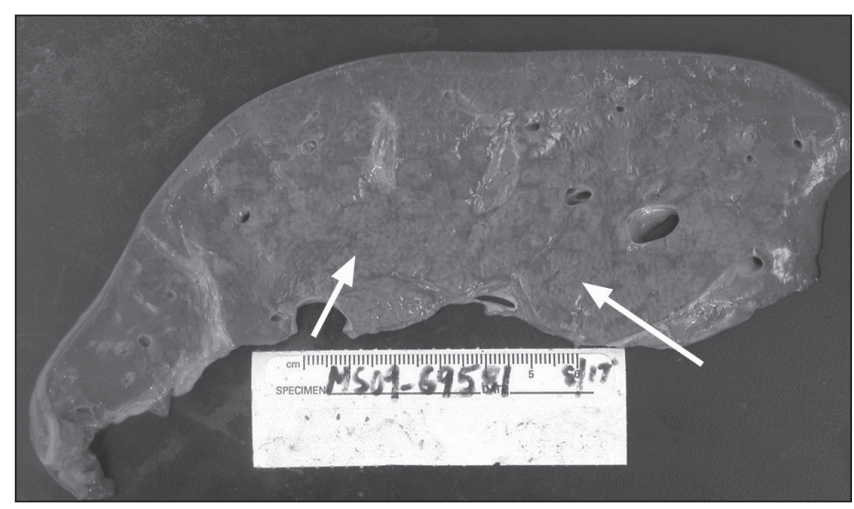

Figure 1) A section from the native explanted liver demonstrating extensive collapse of the parenchyma (seen as hemorrhagic areas) with intervening geographic yellow-tan areas of viable and regenerating parenchyma (arrows)

analgesic/antipyretic, an antiproliferative and as a natural supplement for weight loss. There are no adequate or well-controlled trials to substantiate any claims of effectiveness in humans for any indication (5).

Several previous reports described liver failure associated with the use of LipoKinetix, a multi-ingredient preparation containing usnic acid (6-8). In 2002, Favreau et al (6) reported on seven patients who developed acute hepatitis after using LipoKinetix. This dietary supplement contains sodium usniate, norephedrine, yohimbine, 3-5-diiodothyronine and caffeine; both usnic acid and ephedra alkaloids have been associated with severe hepatotoxicity. LipoKinetix withdrew the product from the market.

Durazo et al (7) reported on a healthy 28-year-old woman who developed acute liver failure within one month of commencing usnic acid (Pure Usnic acid, Industrial strength; AAA Services, USA) $500 \mathrm{mg} /$ day for two weeks (7).

Sanchez et al (8) reported severe hepatotoxicity in a husband and wife (both 38 years of age) who were bodybuilders taking the multiingredient health supplement UCP-1 (BDC Nutrition, USA) for three months. UCP-1 contains usnic acid ( $150 \mathrm{mg})$, L-carnitine $(525 \mathrm{mg})$ and calcium pyruvate $(1050 \mathrm{mg}$ ) per capsule. The wife developed fulminant hepatic failure requiring liver transplantation. The husband experienced submassive necrosis but did not require liver transplantation. Another herbal remedy containing usnic acid - well known to be hepatotoxic - is kombucha tea. This is a beverage made by brewing kombucha mushrooms in sweet black tea (9).

Usnic acid has been shown to uncouple oxidative phosphorylation in a murine model, with resultant loss of mitochondrial respiratory control and inhibition of ATP synthesis. A direct hepatotoxic effect analogous to carbon tetrachloride-induced liver toxicity has also been described (10). Based on a case report (11) detailing three sisters with acute hepatitis after consumption of a 'fat burner' herb containing usnic acid, it was suggested that an inherent susceptibility was present.

Usnic acid is a weak inhibitor of cytochrome CYP2D6 and a potent inhibitor of cytochrome CYP2C19. Based on potent inhibition of CYP2C enzymes, usnic acid has significant potential to interact with other medications (5). Hepatotoxicity due to usnic acid appears to be idiosyncratic and is possibly due to a 'convergence of risk factors' (12).

Chinese green tea extracts are derivatives of the leaves of Camellia sinensis, which belongs to the aceae family. Green tea extracts have been marketed as effective weight-loss supplements, and for the prevention and cure of solid tumours. Although there is little scientific evidence supporting the effectiveness of green tea extracts, serious side effects, including acute liver failure, are increasingly being reported $(13,14)$. Similar cases have been reported from France and Spain resulting in the removal of the green tea extract 'Exolise' from the market (15). Two cases of fulminant hepatic failure associated with green tea extracts have been reported $(16,17)$. Mitochondrial toxicity 

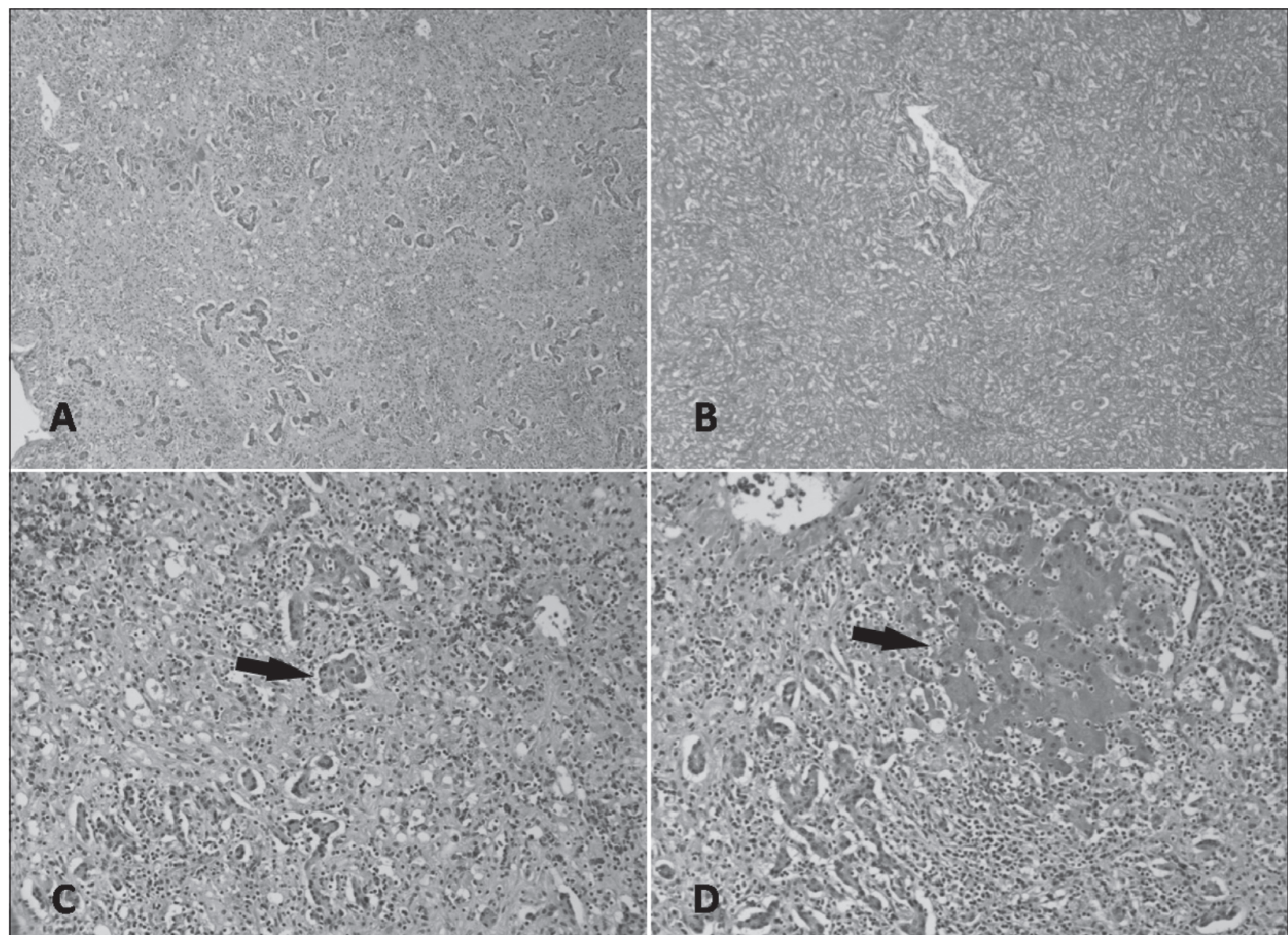

Figure 2) Histology of the native explanted liver. A Low-power magnification showing confluent necrosis resulting in parenchymal collapse (hematoxylin and eosin stain, original magnification $\times 40)$. B Reticulin stain confirming the extensive parenchymal collapse (original magnification $\times 40)$. $\mathrm{C}$ High-power magnification showing the formation of ductular hepatocytes in periportal areas (arrow) (hematoxylin and eosin stain, original magnification $\times 100$ ). D Patchy foci consisting of viable hepatocytes are present (arrow) (hematoxylin and eosin stain, original magnification $\times 100)$

and the formation of reactive oxygen species have been demonstrated with epigallocatechin-3-gallate, a key constituent of green tea extracts. The possibility of an allergic reaction to green tea itself has also been reported (18).

Gum guggul and its constituents are increasingly being used as dietary supplements. Gum guggul is the oleoresin of Commiphora mukul, a plant native to India. Its extracts include compounds known for their hypolipidemic properties - the $\mathrm{Z}$ and $\mathrm{E}$ isomers of guggulsterone and its regulated guggulsterols. Human exposure to gum guggul most often occurs from ingesting herbal remedies or pharmaceuticals, and from the use of cosmetics. Side effects include skin rashes, irregular menstruation, diarrhea, headache, mild nausea and, with very high doses, liver toxicity. Guggulsterol was associated with acute hepatitis in a 63-year-old woman taking the natural lipid-lowering agent Equisterol (Istituto Farmacoterapico Italiano $\mathrm{SpA}$, Italy), which also contains red yeast rice extract (19).

Based on the temporal relationship between the use of the dietary supplements and onset of liver failure, literature supporting reports of hepatotoxicity associated with dietary supplements and exclusion of other causes, it is fair to assume that the patient developed fulminant hepatic failure due to dietary supplements. In view of the bulk of the literature, of all the ingredients, usnic acid may have been predominantly responsible for the hepatoxicity. Although usnic acid was the main hepatotoxic agent, its effect was possibly perpetuated by other hepatotoxins, including green tea and gum guggul, also contained in the dietary supplements taken by the patient.

According to the Dietary Supplement Health and Education Act of 1994, dietary supplements are regulated as foods and are not subject to regulation as drugs by the FDA; manufacturers are not compelled to provide safety data to the FDA. However, increasing reports of liver failure due to usnic acid have triggered a regulatory warning and one voluntary product withdrawal (LipoKinetix) (20). Usnic acid is still available and advertised on the Internet as an ingredient in various other dietary supplements and fat burners. Usnic acid, green tea and guggul tree extracts are a few of the many herbal and dietary supplements associated with significant liver injury.

CONFLICTS OF INTEREST: The authors have no financial disclosures or conflicts of interest to declare.

\section{REFERENCES}

1. Chitturi S, Farrell GC. Hepatotoxic slimming aids and other herbal hepatotoxins. J Gastoenterol Hepatol 2008;23:366-73.

2. De Smet PA. Herbal remedies. N Engl J Med 2002;19:2046-56.

3. Stedman C. Herbal hepatotoxicity. Semin Liver Dis 2002;22:195-206.

4. Stickel F, Patsenkar E, Schuppan D. Herbal hepatotoxicity. J Hepatol 2005;43:901-10. 
5. Foti RS, Dickman J, Davis JA, et al. Metabolism and related human risk factors for hepatic damage by usnic acid containing nutritional supplement Xenobiotica 2008;38:264-80.

6. Favreau JT, Mina LR, Braunstein G, et al. Severe hepatotoxicity associated with the dietary supplement LipoKinetix.

Ann Intern Med 2002;136:590-5.

7. Durazo FA, Lassman C, Han SH, et al. Fulminant liver failure due to usnic acid for weight loss. Am J Gastroenterol 2004;99:950-2.

8. Sanchez W, Maple JT, Burgart LJ, Kamath PS. Severe hepatotoxicity associated with use of a dietary supplement containing usnic acid. Mayo Clin Proc 2006;81:541-4.

9. Centers for Disease Control and Prevention. Unexplained severe illness possibly associated with consumption of Kombucha tea Iowa, 1995. MMWR 1995;44:892-900.

10. Han D, Matsumaru K, Rettori D, Kaplowitz N. Usnic acid-induced necrosis of cultured mouse hepatocytes: Inhibition of mitochondrial function and oxidative stress. Biochem Pharmacol 2004;67:439-51.

11. Hsu LM, Huang YS, Chang FY, Lee SD. 'Fat burner' herb, usnic acid, induced acute hepatitis in a family. J Gastroenterol Hepatol 2005;20:1138-9.

12. Ulrich RG. Idiosyncratic toxicity: A convergence of risk factors. Ann Rev Med 2007;58:17-34.
13. Bonkovsky HL. Hepatotoxicity associated with supplements containing Chinese green tea (Camellia sinensis). Ann Intern Med 2006;144:68-71.

14. Pedros C, Cereza G, Garcia N, Laporte JR. Liver toxicity of Camellia sinensis dried etanolic extract. Med Clin (Barc) 2003;121:598-9.

15. Vial T, Bernard G, Lewden B, Dumortier J, Descotes J. [Acute hepatitis due to Exolise, a Camellia sinensis derived drug.] Gastoenterol Clin Biol 2003;27:1166-7.

16. Molinari M, Watt KD, Kruszyna T, et al. Acute liver failure induced by green tea extracts: Case report and review of the literature. Liver Transpl 2006;12:1892-5.

17. Gloro R, Hourmand-Olliver I, Mosquet B, et al. Fulminant hepatitis during self-medication with hydro alcoholic extract of green tea. Eur J Gastroenterol Hepatol 2005;17:1135-7.

18. Schmidt M, Schmitz HJ, Baumgart A, et al. Toxicity of green tea extracts and their constituents in rat hepatocytes in primary culture. Food Chem Toxicol 2005;43:307-14.

19. Grieco A, Miele L, Pompili M, et al. Acute hepatitis caused by a natural lipid-lowering product: When "alternative" medicine is no "alternative" at all. J Hepatol 2009;50:1273-7.

20. Schiano T. Hepatotoxicity and complementary and alternative medicines. Clin Liver Dis 2003;7:453-73. 


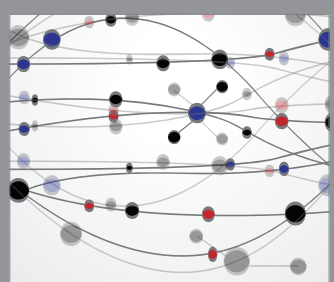

The Scientific World Journal
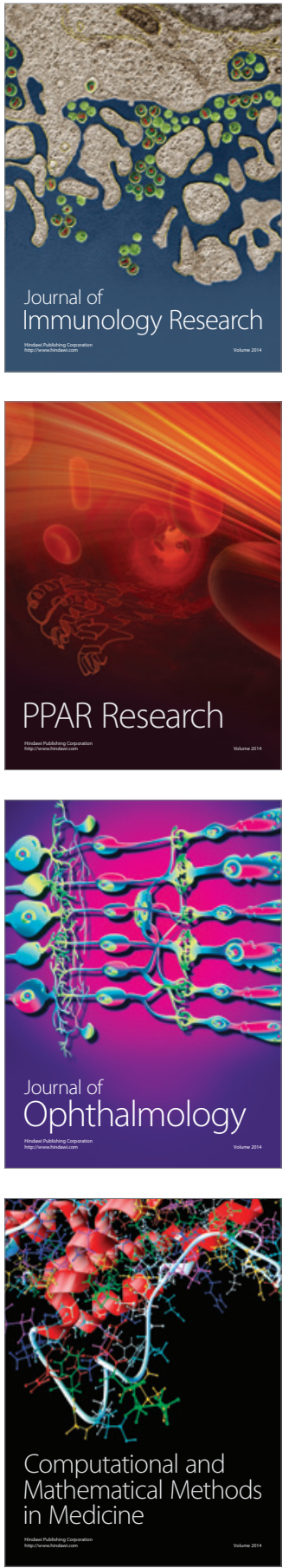

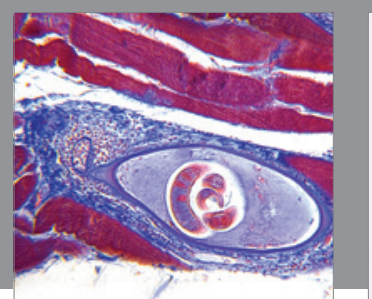

Gastroenterology Research and Practice

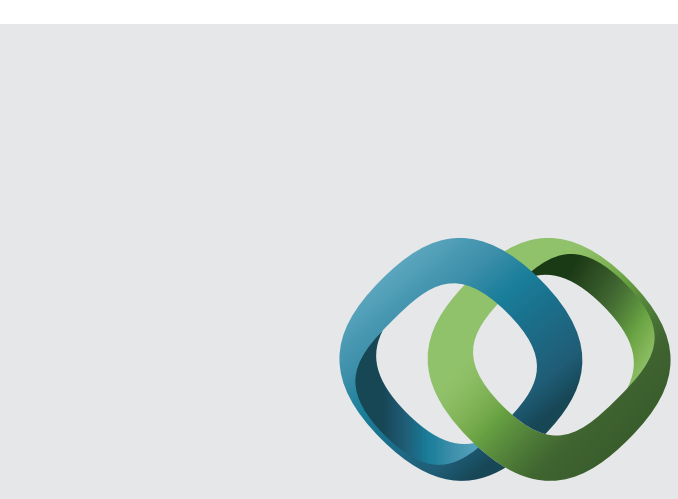

\section{Hindawi}

Submit your manuscripts at

http://www.hindawi.com
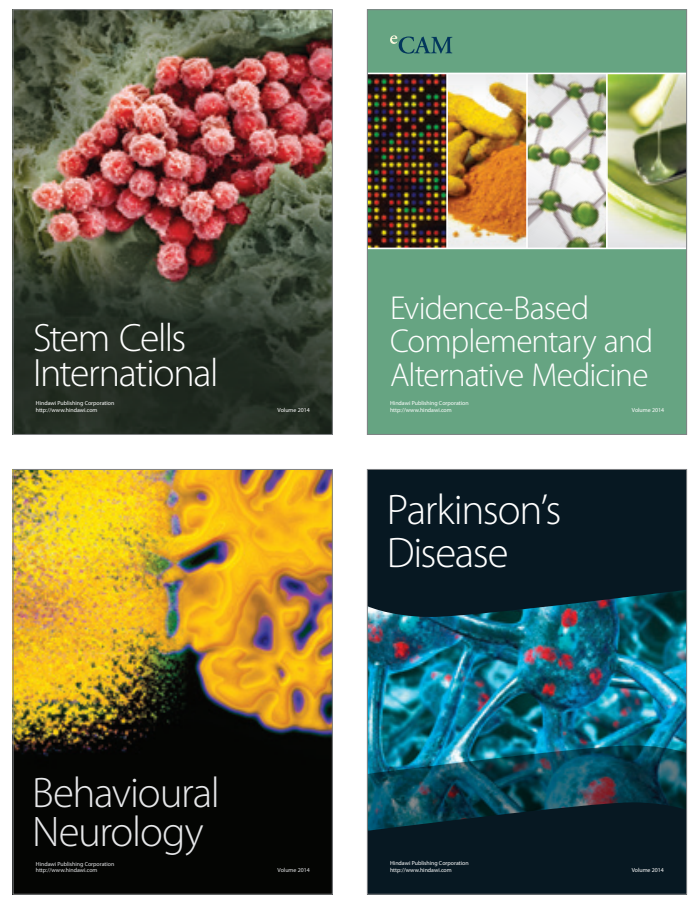
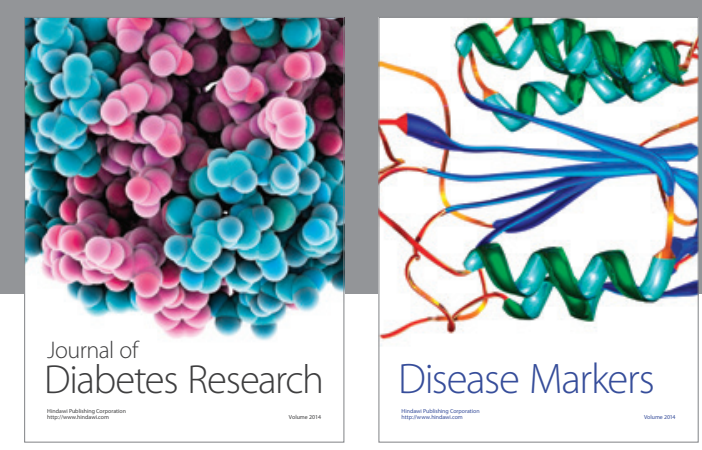

Disease Markers
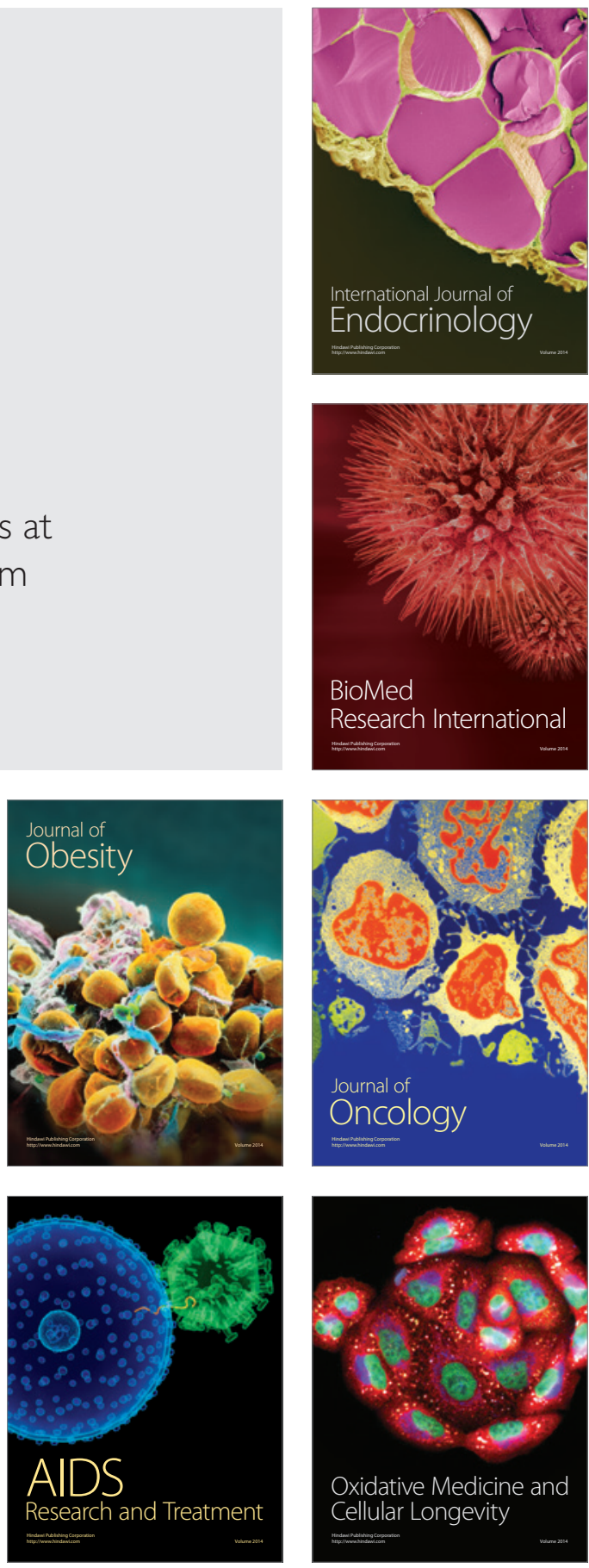